\title{
Subtil exkludering - Exkludering av högpresterande elever med utländsk bakgrund i en innerstadsskola
}

\author{
Layal Kasselias Wiltgren \\ Institutionen för Beteendevetenskap och Lärande, Linköpings universitet
}

\begin{abstract}
Skolsegregations negativa effekter debatteras flitigt där både klass och etnicitet anses påverka elevers möjligheter till att lyckas och där de stora förlorarna är elever från arbetarklasshem som har utländsk bakgrund. Denna studie riktar istället blicken mot en i forskningssammanhang bortglömd grupp, nämligen högpresterande elever med utländsk bakgrund som bor i ekonomiskt bemedlade bostadsområde och går i en innerstadsskola med gott rykte. På ett formellt plan är eleverna inkluderade i det svenska skolsystemet, majoriteten har högutbildade föräldrar som kan hjälpa dem att navigera i det svenska skolsystemet, de har höga ambitioner och höga betyg. Därmed bidrar de till skolans fortsatta goda rykte. På det sociala planet upplever de däremot att de exkluderas av klasskamrater som refereras till som "svenskarna". Denna exkludering uttrycks inte verbalt, utan genom små subtila handlingar i de vardagliga interaktionerna, $\mathrm{i}$ form av mikroaggressioner, något som de exkluderade eleverna kopplar till sin etniska bakgrund. Men eftersom exkluderingen är outtalad och sker subtilt, och eftersom lärarna inte kopplar exkludering till en fråga om etnicitet, blir den svår att ifrågasätta. Resultatet pekar på att formell inkludering inte per automatik bidrar till social inkludering. Studien bygger på deltagande observation $i$ en gymnasieskola och intervjuer med elever såväl som lärare och skolledare.
\end{abstract}

\section{INLEDNING}

Skolsegregationens negativa effekter på elevers möjligheter att lyckas i skolan har på senare år debatterats flitigt. Fokus har riktats mot elever med utländsk bakgrund, dvs. de som själva är eller vars föräldrar är födda utomlands ${ }^{1}$, bosatta i socioekonomiskt utsatta bostadsområden i så kallade segregerade 
förorter (Bunar \& Sernhede, 2013; Jonsson, 2007; Kallstenius, 2010; Runfors, 2003; Sernhede, 2011; Wiltgren, 2016). Ett återkommande tema i ett flertal studier uppmärksammar att dessa elever konstrueras som annorlunda och underordnade, vilket leder till att de marginaliseras och görs till problem som resulterar i uteslutningsprocesser. Dessa studier utgör en bärande grund för förståelse av ojämlikhet i det svenska utbildningssystemet men vi bör även inkludera högpresterande elever och det system som reproducerar deras sociala positioner, det Gaztambide-Fernández (2009) benämner som "studying up".

Denna studie riktar därför blicken mot en i forskningssammanhang förbisedd grupp, nämligen elever med utländsk bakgrund i en innerstadsskola med gott rykte, och som inte är bosatta i områden som kännetecknas av utanförskap och andra former av socioekonomiska problem. De har bra betyg, höga ambitioner och mycket driv. På så vis är de delaktiga i samhället och utgör exempel på hur den eftersökta integrationen, i form av formell inkludering för dem som lärt sig att knäcka koden till det svenska utbildningssystemet, fungerar i relation till etnicitet. Den högpresterande så kallade "invandrareleven" i innerstaden destabiliserar svenskheten eftersom kategorin vanligtvis associerats med förort och låg prestation. Denna kategori har egentligen inget namn. Vi talar sällan om "högpresterande elever med utländsk bakgrund". Det är en kategori som utmanar föreställningar om svenskheten och det ickesvenska.

Lyckade skolprestationer innebär dock inte per automatik att elever inte stöter på problem. Syftet med det övergripande projektet har varit att undersöka vilka framgångsstrategier högpresterande elever med utländsk bakgrund använder, men även vilka sociala hinder och problem de stöter på, och hur de hanterar dessa. I föreliggande artikel kommer jag belysa glappet mellan formell och social inkludering genom att rikta fokus mot hur eleverna talar om vad jag kommer att benämna som en subtil form av exkludering (eng: polite exclusion; Wiltgren, 2020). Syftet med föreliggande artikel är således att undersöka hur högpresterande elever med utländsk bakgrund upplever social exkludering i hur de bemöts, tilltalas och interagerar i skolvardagen i relation till föreställningar kring svenskhet och ickesvenskhet. I fokus ligger elevernas egna erfarenheter, upplevelser och tolkningar.

\section{SKAPANDET AV VI OCH DOM}

En utgångspunkt i denna studie är att etniciteter skapas och görs, men detta skapande kräver en motpol, något som uppfattas som annorlunda (Hall, 2000, s. 147). Eriksen (2007, s. 21 f.) framhåller att etnicitet skapas i mötet med andra grupper och att etnicitet till sin natur inte är en egenskap hos en grupp utan en aspekt av en relation. Själva gruppbildningarna kring etnicitet kan bara ske genom att upprätta gränser. 
I slutet på 1960-talet flyttade antropologen Fredrik Barth (1994) fokus från att studera kärnan i etniska grupper till att studera gränser och relationer mellan grupper. Barth menar att gränserna, liksom medvetenheten om och upprätthållandet av dem, är en förutsättning för att etniska grupper ska kunna existera. Fokus bör därför riktas mot upprätthållandet av gränserna (Barth, 1994). Svenskhet har beskrivits som en gräns dragen kring en vit tillhörighet formad genom föreställd likhet och olikhet och handlar om hur man uppfattas av andra snarare än om ens egen självbild (Mattsson, 2005).

Lamont \& Molnár (2002) lyfter fram betydelsen av symboliska gränser, som syftar till att kategorisera omvärlden, inklusive människor, för att göra den begriplig. Genom symboliska gränser skapar vi likheter och skillnader mellan individer och grupper, (såsom etnicitet, kön och klass), där vissa inkluderas i gruppmedlemskap och samhörighet, de uppnår social status och berättigas resurser. Då enighet råder kring symboliska gränser kan de övergå till sociala gränser och bli begränsande för grupp och individ.

I sitt klassiska verk lyfter Gordon Allport (1979) fram vårt medfödda behov av att generalisera och kategorisera allt i vår värld, inklusive människor, och att vi har en medfödd benägenhet till fördomar. Vi är vanemänniskor som av bekvämlighetsskäl föredrar människor som är lika oss själva. Däremot menar Allport att fördomar kan minska genom interaktion och kamrateffekten. Enbart kontakt räcker dock inte, frågan är mer komplex än så. Det är genom att sträva mot gemensamma mål och genom att skapa en vi-känsla understödd av auktoritet, exempelvis skolan, som fördomar minskar (Allport, 1979). Skolan har med andra ord ett ansvar; det är svårt för enskilda elever att åstadkomma förändring på egen hand.

Allports kontakthypotes föreslår att kontakt mellan etniska grupper bidrar till tillit, tolerans och solidaritet mellan människor, medan konflikthypotesen utgår från att mångfald leder till konkurrens över resurser, misstro mot utgruppen och stärkta band till ingruppen. Robert Putman (2007) visar att båda grundantagandena är bristfälliga. I mångkulturella lokala samhällen råder visserligen misstro, men inte enbart mot utgruppen, utan även gentemot ingruppen. Så vita amerikaner misstror även andra vita amerikaner, vilket förkastar både hypoteserna. Putman föreslår istället constrict theory som även tar hänsyn till individens sociala kapital. Människor som bor i etniskt blandade områden, tenderar att ha lägre socialt kapital i form av sociala nätverk, vilket i sin tur påverkar deras syn på och relation till samhället i stort, till lokalsamhället, och till människorna som bor där. En av Putmans slutsatser är: där social närhet är stor, känner vi samhörighet och gemenskap, men där den sociala distansen är stor, råder ett avståndstagande och en exkludering ur gemenskapen. Putman menar att vi behöver rekonstruera sociala identiteter, inte enbart migranters utan samhällets i stort, samtidigt som vi uppmuntrar multipla identiteter som ser sig själva som en del av samhället. Den stora utmaningen för moderna samhällen är därmed inte att göra immigranter som 
"oss", utan att skapa ett nytt, brett och inkluderande "vi", genom att rekonstruera mångfald som inte suddar ut etniska skillnader, utan skapar övergripande identiteter (Putman, 2007).

Trots att gränserna har blivit mer flytande vore det ett misstag att utgå från att kategoriseringar blivit oviktiga. Frågor kring identiteter har snarare blivit allt viktigare med tiden (Hall, 2000). Frågan kring tillhörighet aktualiseras främst när man själv blir exkluderad (Anthias, 2006). På ett liknande sätt menar Sara Ahmed (2010) att vita kroppar smälter så väl in med omgivningen att de blir bekväma och känner sig hemma i institutionella sammanhang, alltmedan icke vita kroppar blir synliga, obekväma och stoppade.

Ahmed framhåller att vithet inom institutioner såsom skolan är osynlig för dem som besitter den, men även för dem som blivit så vana vid dess normerande makt att de lärt sig att inte se den trots att de själva inte är inkluderade $\mathrm{i}$ den. Ahmed menar vidare att rum orienteras mot vithet och resulterar i en institutionalisering av en viss "likhet" som får icke vita kroppar att känna sig obekväma, utsatta, osynliga och annorlunda när de tar upp detta utrymme (Ahmed 2010, s. 58).

Utbildningssystemet gynnar med andra ord vita elever från resursstarka hem, men högpresterande elever tenderar att se sin framgång i meritokratiska termer; det är deras hårda arbete som berättigat dem privilegier (Törnqvist, 2015). Framgångsrika elever som inte hör till normen i fråga om klass och hudfärg möter dock problem $i$ form av fördomar, exkludering och osynliggörande från såväl skolan som institution som skolkamrater och lärare (Kuriloff \& Reichert, 2003; Lund, 2015). Medvetenheten om riskerna med att socialt inte höra hemma i elitskolor gör att många högpresterande elever med utländsk bakgrund väljer bort dessa skolor, trots att de har de betyg som krävs (Bunar, 2010; Lund, 2015). De som söker sig till högpresterande skolor där majoriteten av eleverna är vita med medelklassbakgrund, känner krav på anpassning inte bara akademiskt utan även socialt (Gaztambide-Fernández, 2009; Kuriloff \& Reichert, 2003; Lund, 2015). Elever som inte lever upp till kraven riskerar olika former av utstötning.

Inom forskningsfältet kritiska rasstudier uppmärksammas mikroaggressioner, en subtil form av rasism som manifesteras genom vardagliga, subtila, verbala och icke verbala nedsättande handlingar riktade mot minoriteter. Eftersom mikroaggressioner uttrycks subtilt, ofta saknar onda intentioner, och är i vissa fall outtalade, kan de verka harmlösa och därför svåra att ifrågasätta. Samtidig kan deras effekter vara smärtsamma för de utsatta (Kholi \& Solórzano, 2012). Effekten av en enskild mikroaggression kan vara minimal, men när de kontinuerligt upprepas riskerar effekterna att kulminera i diskriminering (Sue, 2010). Forskningstraditioner av idag uppfattar etnicitet som socialt konstruerat men empiriska studier pekar på att etnisk bakgrund påverkar hur vi relaterar till människor (Gruber, 2007; Kallstenius, 2010; Lund, 2015; Runfors, 2003; Wiltgren, 2014). 


\section{METOD OCH BESKRIVNING}

Denna studie tar sin utgångspunkt $i$ en anrik innerstadsgymnasieskola $i$ en medelstor svensk stad. Under en termin följde jag en gymnasieklass under lektioner, raster och i matsalen. Programmet har internationell inriktning och kräver godkänt inträdesprov i matematik och engelska, som är arbetsspråket. Majoriteten av skolans elever har svensk bakgrund. Klassen jag följer har internationell inriktning och lockar många elever med utländsk bakgrund som utgör cirka två tredjedelar av klassammansättningen. Rektorn rekommenderar klassen i samråd med lärare, med motiveringen att det är en klass med ambitiösa, högpresterande elever, men även att klassen utgör ett bra exempel på lyckad integrering. De flesta elever kommer från medelklasshem och har högutbildade föräldrar. En stor andel är födda i Sverige men har föräldrar som har migrerat, en del elever är nyanlända som lockas av att arbetsspråket är engelska.

De nyanlända har i vissa fall följt med föräldrar som fått arbete i Sverige, men några kommer från konfliktdrabbade områden, eller är här för att studera. Utöver deltagande observation utförde jag 36 enskilda intervjuer med elever, 1 gruppintervju (med 5 elever), 5 enskilda intervjuer med lärare, samt 1 enskild intervju med skolledare. Eleverna liksom lärarna fick välja om de ville hålla intervjuerna på svenska, engelska eller båda språken. En av intervjuerna hölls på engelska och arabiska. Forskningsprojektet är etiskt granskat och alla namn som förekommer $\mathrm{i}$ texten är fingerade. Analyserna bygger på tematisk analys där intervjutranskriptioner kombineras med fältanteckningar i en kodning vars syfte är att upptäcka återkommande teman som relaterar till studiens syfte (jfr Braun \& Clarke, 2006). Tematisk analys bygger på otaliga läsning av det insamlade materialet i sökande efter teman, det vill säga sammanhängande och meningsfulla mönster i materialet som har relevans för forskningsintresset. Vissa teman uppmärksammades redan i ett tidigt skede av studien. Ett sådant var den exkludering elever med utländsk bakgrund beskrev redan vid vårt första möte, och som jag sedan kunde observera och utforska under intervjuerna.

Studien tar sin utgångspunkt i skolvardagen, men de handlingar och erfarenheter som utspelar sig där är en del av en större kontext. George Marcus (1998) ser etnografi som strategiskt situerad med vilket han menar att lokal etnografi kan hjälpa oss att förstå inte bara det lokala subjektet, utan även något mer generellt, till exempel hur inkludering och exkludering kan samverka, i en större samhällskontext.

\section{TYDLIGA MEN OUTTALADE GRÄNSER}

Längst bak i klassrummet sitter Maral, Tuva, Patrick, och Ida på rad. Eleverna arbetar enskilt och koncentrerat med att lösa uppgifterna i 
biologiboken. Plötsligt suckar Tuva högt och talar uppgivet om att hon inte förstår.

Patrick skrattar vänskapligt åt hennes höga suck och börjar förklara. Maral skrattar med och försöker hjälpa honom med förklaringen. När Patrick talar nickar kamraterna instämmande, de håller ögonkontakt och bekräftar med små, subtila m-ljud. Men när Maral talar, tystnar de andra, de kastar en hastig blick mot henne, men vänder snabbt bort blicken.

Patrick fortsätter sin förklaring och frågar om Tuva förstår. Det gör hon inte och alla skrattar. Även Maral skrattar, men ingen tittar på henne. Maral frågar om de har gjort uppgiften på sida 86. Tuva stirrar med en tom blick framåt, medan hon skakar på huvudet. Patrick skakar också på huvudet, med blicken fäst i bänken. Ida skruvar på sig men svarar inte.

Gör man den uppgiften så klarnar det, fortsätter Maral. Ingen svarar. Patrick återupptar samtalet, de skojar och skrattar. Maral gör ett flertal försök att skratta med, hon sticker in kommentarer som passar in i deras samtalsämne, och vid de tillfällena bekräftar de henne genom en hastig blick, genom att nicka kort eller svara enstavigt på hennes frågor.

Under hela lektionen är det ingen som ställer frågor till Maral eller nappar på samtalsämnen hon introducerar. Svaren hon får består av ja eller nej. Men ingen är verbalt otrevlig eller elak mot henne. Klasskamraterna besvarar trots allt hennes frågor och de tittar emellanåt på henne när hon talar. Däremot tar de inga initiativ till att tilltala henne, de behåller inte ögonkontakt och Tuva som sitter närmast, sitter aningen vänd bort från Maral, med ryggen lite mot henne. Dessa och liknande former av mikroaggressioner kan vara svåra att opponera sig mot, eftersom de är subtila, outtalade och saknar förmodligen onda intentioner (Kholi \& Solórzano, 2012; Sue, 2010).

Eleverna i klassen har bestämda sittplatser som de själva gör anspråk på. De som kallas svenskarna, där Patrick, Tuva och Ida ingår, sätter sig utmed högra sidan av klassrummet. Resten, som utgör cirka två-tredjedelar av klassen, sitter utspridda utmed klassrummets vänstra sida och mitt. Men ibland hamnar man på "fel" sida, som Maral tycktes göra den dagen. Endast några få elever bryter mot de oskrivna reglerna och förklaras av eleverna som undantag. Emanuel beskriver det som följande; "there might be like two Swedish among us but they have very different personalities from the ones sitting on the other side".

Uppdelningen i klassrummet är iögonfallande, och när jag intervjuar eleverna i slutet av fältarbetet nämner påfallande många elever med utländsk bakgrund uppdelningen, som de kopplar till etnicitet, utan att jag specifikt frågat om den. Maral berättar följande:

Man brukar snacka typ såhär "ah [namnet på klassen] är jättebra för man har så många olika kulturer" men de spelar ju ingen roll, för man blir ju 
fortfarande, ah, de är ju vi blattarna och sen är det dom svenskarna. De blir, de är ju bara så de blir. (Maral)

Elever med utländsk bakgrund, oavsett om de är nyanlända eller födda i Sverige, beskrivs av skolpersonal och ledning i föreliggande studie som resurser som berikar skolans kultur. Under en intervju beskriver rektorn klassen som ett lyckat integrationsprojekt. Lärarna beskriver eleverna som högpresterande, ambitiösa, skötsamma och hårt arbetande. På så vis bidrar de till skolans fortsatta goda rykte och skiljer sig från den gängse bilden av elever i så kallade socialt utsatta områden.

Oavsett skolprestation brottas elever med utländsk bakgrund med liknande problem vad gäller inkludering och kontakt med jämnåriga svenskar (jfr Hagström, 2018; Nilsson Folke, 2016; Wernesjö, 2015). Inkludering kan hänvisa till graden av individens känsla av att vara involverad i beslutsfattande, och ha tillgång till resurser och information, men den kan även inbegripa en känsla av tillhörighet och att vara uppskattad för sina unika egenskaper. En teoretisk utgångspunkt är att inkludering och exkludering mycket väl kan samexistera.

Trots att eleverna i föreliggande studie har sökt sig till ett internationellt, engelskspråkigt gymnasieprogram är den etniska segregationen påtaglig. Så här beskriver två nyanlända elever segregationen i klassen.

They [The Swedish classmates] won't let other people, unless you are Swede to be in their group, so I think that's kind of segregation. (Christine)

The [name of the class] tries to unite people and give you international perspective and accept other cultures, and I don't really understand why they [the Swedish students] will join such a program that has those standards, when really you want to be isolated in your culture, you know. And it's so extremely clear in the classes; foreigners, Swedish. (Emanuel)

Christine beskriver uppdelningen i termer av exkludering och segregation och Emanuel betonar att uppdelningen är extremt tydlig. Både riktar fokus mot dem som upprätthåller gränserna som avvisar dem som inte betraktas som svenskar och isolerar sig i sin egen kultur. De som beskrivs som svenskar görs i Christines och Emanuels beskrivning till agenter med makt att tillåta eller avvisa klasskamraters tillträde till sociala grupper. Påfallande många elever nämner segregationen i klassrummet utan att jag specifikt frågat om den. När jag frågar Hassan hur han upplever den sociala miljön nämner han grupperingar i klassen och fortsätter.

- De grupper som jag ser, svenskarna, eller dom som har bott i Sverige väldigt länge, så de pratar väldigt mycket... flytande svenska. 
- Men är de svårt å, tror du de är svårt å ta sig in i den här gruppen om man nu skulle vilja?

- Asså, jag vet inte. Vet inte! De verkar, asså, du måste anstränga dig! Du måste ändra dig! Du måste ändra din personlighet!

- Till? Till vaddå?

- Ja, till vad dom är! [fnyser] Jag vet inte vad dom är [skrattar]. (Hassan)

Ansvaret för att potentiellt bli inkluderad i gruppen "svenskarna" vilar på Hassan själv genom att anstränga sig, ändra sig själv och sin personlighet. Han behöver med andra ord bli mer lik dem för att inkluderas i gemenskapen. Samtidigt säger Hassan att han inte vet vad de är, vilket försvårar inkluderingen. Den rådande diskursen om inkludering, menar Ahmed (2012), riskerar att göra de som ska inkluderas till själva problemet. Det är Hassan som belastas med problemet och samtidigt förväntas finna lösningen.

När jag, i en gruppintervju med fem av de elever som beskrivs som svenskarna, frågar hur de upplever den sociala miljön i klassen, nämner även de, uppdelning i klassrummet. Hugo förklarar att "vi är en kärngrupp och så finns de som kommer in då och då”. Men uppdelningen förklaras inte i termer av etnicitet. Istället lyfter de fram interna likheter och gemensamma intressen som förklaring till sin fina gemenskap. Elsa förklarar "vi är på ett eller annat sätt lika allihopa" och Patrick tillägger" och vi har samma slags humor". Elin förtydligar att "jag tror man känner av vilka som är lika en själv typ". Deras svar får mig att fråga "så det krävs någon slags likhet?" och Elsa bekräftar "Ah, lite". Hennes kamrater nickar instämmande.

Hassan är med andra ord inte helt fel ute i sin analys: för att bli inkluderad krävs en form av likformighet. Krav på anpassning genom att ändra personlighet återkommer i andra studier (Gaztambide-Fernández, 2009; Kuriloff \& Reichert, 2003; Lund, 2015; Wiltgren, 2020). För att potentiellt bli inkluderad måste Hassan tillskansa sig likheter till gruppen utan att vara del av den. Detta leder till ett moment-22: för att bli inkluderad krävs att man är lik, men för att bli lik, behöver man vara inkluderad. Effekten blir att endast de som redan är lika blir inkluderade. Det är också förklaringen till de få elever som trots sin utländska bakgrund lyckats vinna acceptans bland Hugo, Elsa och deras kärngrupp. "They are more Swedish" förklarar Emanuel.

Svenskhet i det här fallet är inte något påtagligt eller formellt. Svenskhet har beskrivits som en symbolisk gräns som möjliggör eller hindrar känslor av social tillhörighet och gemenskap, samtidigt som den utgör tecken på status och social prestige (Lund, 2015, s. 78). Det handlar inte om var man är född eller vad man "är". Michael Azar (2006) framhäver att svenskhet endast kan definieras genom sin utestängande funktion. Detta gör att svenskhet är en avsaknad av det osvenska. Ahmed (2010) lyfter fram att institutioner är orienterade kring vithet så att till och med kroppar som inte ser vita ut ändå måste besitta vithet för att bli inkluderade. 
En del av förklaringen till bristande kontakt mellan svenska elever och elever med utländsk bakgrund är att de inte möts (Möller, 2010; jfr Allport, 1979). Men den rumsliga segregationen som råder på många håll i samhället, genom exempelvis boendesegregation och skolsegregation (jfr Sernhede, 2011) eller genom att nyanlända elever kan fastna i mottagningsklasser (jfr Hagström, 2018; Nilsson Folke, 2016) existerar inte här. Här möts elever i skolans korridorer och i klassrummet, på relativt lika villkor vad gäller utbildning och skolarbete. Eftersom arbetsspråket är engelska kan nyanlända fortsätta sina studier direkt istället för att påbörja språkintroduktion där risken att fastna i flera år förekommer. Men formell inkludering leder inte per automatik till social inkludering. Snarare beskriver eleverna ett outtalat avståndstagande, en subtil form av exkludering. Flera elever nämner att de endast tilltalas av nödtvång, då skoluppgifter kräver kommunikation (jfr Langmann \& Månsson, 2016). Emanuel uttrycker det så här: "when it is extremely necessarily, they will have to speak with me".

Trots att kamraterna talar med Emanuel upplever han att samtalet med honom bygger på ointresse och ett slags artighet och plikt. Christine lyfter fram att klasskamraterna svarar henne när hon talar med dem, men mer av artighet än intresse, och hon drar slutsatsen att de inte ämnar inkludera henne i sin sociala grupp. På så vis kvarstår en exkludering trots dagliga möten och samtal.

I mean they would like, you know, talk to you and that, but you would feel yourself like "oh this person doesn't like me". Or this person just want to talk to me cause I'm talking to him or her, but is not actually going to, like include me in the, for example their kind of squad. [...] Haven't you noticed like no one except them have actually, you know, like, tried to, get in to their group because it's like always been like that. (Christine)

När det framstår som oundvikligt blir Emanuel och Christine tilltalade. Samtidigt förmedlas ett budskap i form av mikroaggressioner, om att de berörda klasskamraterna i själva verket inte tycker om dem, inte vill tala med dem eller inkludera dem i sin sociala grupp. När Christine har försökt förmå mig att förstå stannar hon plötsligt upp och undrar förvånat, lite förebrående, huruvida jag inte har lagt märke till de processer hon beskriver, jag har ju tillbringat en hel termin i klassen. Istället för att svara på hennes fråga ställer jag ännu en, där jag frågar Christine vad hon tror att det upplevda avståndstagandet beror på.

- They think that we're weird.

- Why?

- Because I don't know, we don't, we are not like them.

- In what sense?

- We're not swede enough [laughs]. (Christine) 
Christine drar slutsatsen att klasskamraterna uppfattar henne som konstig eftersom den grupp hon anses tillhöra uppfattas som konstig, inte som "dem" i bemärkelsen inte tillräckligt svensk. Uppdelning uppfattas som både uppenbar och rigid att Emanuel beskriver den i metaforen av att leva i olika världar.

They want to have like their own world, they only speak Swedish among them. They don't talk to you, like you, you probably have seen that in every class. (Emanuel)

Uppdelningen i svenskar och andra som Emanuel beskriver $i$ termer av skilda världar, nämns inte under intervjuerna med de elever som har svenska som modersmål eller med lärarna. När jag tar upp ämnet, medger lärare att de har tänkt på segregationen, men förklarar den täta sammanhållningen bland de elever som benämns som svenskarna med att de har gått i samma skola tidigare och pendlar från samma område. När jag frågar eleverna själva visar det sig att de bor långt ifrån varandra, har skilda resvägar till skolan och att de varken gått i samma skolor eller känt varandra sedan tidigare. Däremot förklarar Elin att "det gick väldigt fort att bestämma vilka man ville umgås med". En motvilja att se segregationen i klassrummet som en fråga om etnicitet har beskrivits i termer av färgblindhet (se Bonilla-Silva, 2017; Bucholtz, 2011). De som exkluderas ur gemenskapen intar istället en inkluderande position sinsemellan.

They always stick together, they're always in a circle, they always stand in a circle. Where's the rest, everyone else, that's not excluding the left or right, this is everyone else except for the eight people who're standing in the circle. Everyone else is moving, going talking to this person and moving to that person and moving to this person and moving to that person. We tend to move around, during the tenancies that we have, asking people "how are you?" and stuff. Whilst, I haven't yet seen some of the people in that circle come up to anyone else other than that circle and say "hey, good morning, what's up?" I haven't yet seen it. And every time I'm passing them I always greet them cause I know they're there and I say "good morning" and they say good morning back. But, I have never seen them have the initiative. (Ali)

Kontakt är eftersträvansvärt, men intresset upplevs inte som ömsesidigt. Ali beskriver klasskamrater som rör sig runt och kallpratar med andra, förutom de åtta elever som alltid håller ihop, som besvarar hälsningsfraser, men inte påbörjar dem. I Alis beskrivning framträder en tydlig "vi" och "de"-diskurs, där den ena gruppen söker kontakt och den andra stänger dörrar. Initiativet att inleda och upprätthålla samtalet hamnar på Ali och de som söker kontakt och resultaten manifestas i mikroaggressioner, genom subtilt avståndstagande 
och korthuggna svar som inte lämnar något större utrymme för samtal. Allport (1979) framhåller att endast kontakt, exempelvis genom att placera elever i samma klass, inte är tillräckligt för att de ska bilda vänskapsband och interagera. En vi-känsla behöver utvecklas, men eleverna klarar inte av att skapa den på egen hand (jfr Putman, 2007), trots att viljan finns från den ena sidan.

\section{KORTA SVAR OCH STÄNGDA DÖRRAR}

If you start asking questions for example, they will just answer with really short answers and end the conversation. And they will just start talk to each other, they will just start talking Swedish.

- And that's a way of doing what?

- Ignoring your, just isolating you, from their group, if you want to enter their group. (Jozef)

Att kodväxla från ett språk till ett annat kan vara ett sätt att utestänga (Wiltgren, 2014), något som Jozef benämner som att bli ignorerad, isolerad och exkluderad. En annan strategi Jozef nämner är när klasskamrater svarar kort och enstavigt, vilket tolkas som ett bristande intresse för att hålla igång samtalet. Dessa mikroaggressioner är svåra att ifrågasätta eftersom de är subtila och outtalade (Sue, 2010; Wiltgren, 2020). Traditionell mobbningsforskning pekar ut ett antal kriterier för definition av mobbning, bland annat att det ska vara en ondsint handling avsedd att tillfoga skada (Olweus, 1998). Denna typ av utsatthet förekom inte under mina observationer och beskrevs inte under intervjuerna. Ingen är verbalt elak. Jozef får aldrig höra att klasskamraterna inte gillar honom eller att de inte vill tala med honom. Däremot förmedlas ett ointresse. Eftersom det rör sig om subtil exkluderingen snarare än explicit blir den svårare att bemöta.

They give off the vibe that they don't want to talk to you. [...] They would just give a yes or no, but they wouldn't take the conversation further. (Andrea)

Klasskamraterna besvarar Andreas frågor. Svaren är dock korta och manar inte till fortsatt samtal. Därför tolkar Andrea deras reaktioner som att de inte vill prata med henne. De är artiga men ointresserade.

Eftersom eleverna har olika ämnesval hamnar de ibland ifrån sina nära vänner. Jag observerar hur Ali ofta utnyttjar dessa tillfällen för att skapa kontakt med sina svenska klasskamrater men han möts av undvikande och korta svar i sina försök att starta en konversation. Så här beskriver han själv hur han försöker närma sig August: 
I tried to have a conversation with him and he kept on giving me short answers, and it, it was like "eh, what have you been doing the last few days?" "Nothing!" [shrugs and pauses] "nothing!"[pauses and stares at me]. That was his answer. How does someone continue from there? When someone direct gives you a cold answer. Other people usually say "eh, not much, actually you know, just going around". And you can continue from there, but when someone just say "Nothing", that cold "nothing!". You know when someone is uninterested in talking to you. But I'm still trying, I was like "What do you mean, you were just sitting at home?" and he was like "Nah, I was just at home, yeah". And, it's really hard to connect with someone that does not wanna talk [...] You knock on the door and they open and then they close immediately, like a door slam in your face... (Ali)

Ansvaret att initiera och hålla liv i samtalet vilar på Ali, gör han inte det existerar inget samtal. Återigen är det ingen som är direkt otrevlig eller elak. August svarar trots allt på Alis frågor. Samtidigt förmedlar han ett bristande intresse. Trots att han liknar kontaktförsöken vid en stängd dörr, förklarar Ali att man aldrig får ge upp, eftersom det vore det yttersta beviset på att man själv har misslyckats och gett upp på sig själv. Men hur tar man sig igenom en stängd dörr frågar jag Ali, som glatt förklarar att:

You keep knocking! Eventually the person will open the door. You can't, you can't keep the door shut forever. Keep knocking and the person will finally get irritated and open it up for you.

Tillträde till den eftersökta gemenskapen vilar på Ali som ensam förväntas finna en lösning, en väg in. Ansvaret för inkludering riktas mot dem som söker inkludering och inte mot dem som exkluderar (jfr Ahmed, 2012).

\section{ATT INTE BLI HÄLSAD PA}

Den rådande statusskillnaden mellan vilken grupp som tar initiativ och söker kontakt och de som avvisar, försvårar vad som skulle kunna utgöra en grogrund för vänskap och interaktion (Allport, 1979). Trots att uppdelningen beskrivs i metaforer av stängda dörrar och att leva i olika världar söker eleverna kontakt med klasskamrater som beskrivs som svenskar, men stöter då på motstånd som manifesterar i outtalade och subtila former av avståndstagande.

Det är tidig morgon och korridoren där eleverna har sina skåp är nästintill tom. Andreas pappa är svensk, hennes mamma är från Indonesien. Andrea har bott i Sverige under ett år och håller på att lära sig svenska. Hon är en av skolans ambitiösa elever, som satsar högt och kämpar hårt. Nu är hon på väg till sitt skåp. 
I skolkorridoren där majoriteten av klassens elever har sina skåp möter hon Elsa. Elsa har precis plockat fram sina böcker och är på väg till klassrummet. Tjejerna är på väg att passera förbi varandra i korridoren. Andrea söker ögonkontakt, hon ler igenkännande mot Elsa, just som blickarna möts öppnar Andrea munnen, det är tydligt att hon vill hälsa.

I samma ögonblick vänder Elsa bort blicken, hon stryker närmare korridorsväggen, bort från Andrea, och fäster blicken i väggen medan hon passerar. Andrea sluter läpparna, det glada leendet försvinner och hon verkar koncentrerad och stressad när hon gräver fram sina böcker ur skåpet. Elsa har hunnit en bit bort i korridoren, där möter hon vännen Elin.

Från håll ser man hur tjejerna hälsar glatt på varandra, de står nära och Elsa tar Elin i armen. De fnissar åt något, samtidigt som de går bort till klassrummet. Under lektionen sitter Elsa och Elin där de alltid sitter, utmed klassrummet högre sida tillsammans med sina vänner Patrick, Hugo och August. Alla har de svenska som modersmål och de kallar sig själv för en kärngrupp när jag intervjuar dem, sedan räknar de upp ett antal elever från klassen som de brukar umgås med. Andrea är inte en av dem.

Andrea är inte den enda som denna så kallade kärngrupp inte hälsar på. När jag intervjuar dem frågar jag om de känner sig utanför och om det är därför de alltid håller ihop. De verkar till en börja inte förstå frågan. Sedan förklarar de för mig att det bara är naturligt att man inte kan umgås med alla i en klass. Denna slutsats dras av fler elever, både i denna och andra studier (se exempelvis Gaztambide-Fernández, 2009), men eleverna i denna studie betonar samtidigt vikten av att hälsa och kunna samtala.

Ali har utvecklat en strategi som innebär att alltid initiera hälsningsfraser och de hälsar alltid artigt tillbaka. Gör han inte det passerar han till synes obemärkt. Jozef har en motsatt strategi, han har slutat hälsa. Han förklarar att han har förstått att de inte tycker om att hälsa på honom, att de känner ett visst obehag inför att besvara hans hej. Han tycks mena att han inte vill utsätta dem från obehaget det medför att hälsa på honom och samtidigt skona sig själv från ett tydligt avståndstagande. Med sorgsen röst förklarar han uppgivet:

I used to say hi to everyone but some of them just start not look me in the eye when I pass. Okay, he don't want to say even hi, so I just like "okay". (Jozef)

Jozef betonar en stund senare att han inte bryr sig, att de inte är hans vänner utan bara klasskamrater. Han kontrasterar mot sin gamla klass i Syrien med gemenskap och sammankomster. Trots att Jozef rycker på axlarna och talar om att han inte bryr sig upptar beskrivningen en stor del av intervjun, utan att jag specifikt frågat om den. Varför bemöda sig om att beskriva något så ingående som man inte bryr sig om? Att rycka på axlarna och tala om att man 
inte bryr sig är ett sätt att hantera avståndstagande. Allport (1979) lyfter fram de starka följder som avvisande, från vad han som betecknas som referensgrupp, kan medföra för de utsatta i form av skam, skuld, och sorg. Christine talar om att hon känner sig ledsen men att hennes strategi är att försöka låta bli att tänka på det eftersom det ändå inte leder någonvart.

I wish they were more open and I wish they were more caring about other people. It's just hard sometimes. But I try not to think about that. Because I would feel sad and I wouldn't achieve anything from being sad. (Christine)

\section{ROTEN TILL RASISM}

Varför är det viktigt att hälsa i skolkorridoren, visa intresse för klasskamrater genom att kallprata och inkludera dem i sociala sammanhang? Andrea förklarar för mig att "det är deras land” och därmed är de den starkare gruppen, de med mer makt och inflytande. Därför får deras avståndstagande en annan innebörd än om en grupp med låg status hade utfört samma handling (jfr Allport, 1979). När Andrea beskriver sina känslor förmedlar hon en sorg över situationen, men ingen förebrålse.

I think it kind of makes me feel inferior, because, they, they are not trying to but it's just that I kind of feel like you know, this is their country, they're the Swedes. Like, we're, we just came here nanana, but, of course that's not what they're doing. No, they can't help it if they can only relate to themselves because they come from the same country. But, I just kind of feel like, why can't we like all, talk to each other and be friends? (Andrea)

Andrea vänder problemet bort från de klasskamrater som hon benämner som svenskarna. Likt flertalet elever uppmärksammar hon att det finns problem, men på grund av att exkluderingen sker subtilt lämnar den inga legitima anledningar till protester. Minoritetsgrupper är enligt Allport (1979, s. 38) nödgad att förhålla sig till majoritetsgruppen som sin referensgrupp i relation till språk, normer, moral och lag. Därför blir deras fördomar mer påtagliga, även om de är av mildare karaktär.

Det händer att eleverna konstaterar att "svenskarna vill inte vara med oss" eller "vår klass är uppdelad". Trots detta är det endast två elever som nämner ordet rasism. Emanuel är en av dem, han talar ursäktande om att han själv låter som en rasist när han beskriver svenskar som inåtvända och kulturellt inskränkta. Den andra är svenskfödda Poneh, vars föräldrar har bakgrund i Iran. Hon betonar att "jag tror inte att det handlar om rasism". Tidigare har hon beskrivit uppdelningen $\mathrm{i}$ termer av olyckliga omständigheter, såsom att inte dela gemensamma intressen. Jag frågar henne vad denna uppdelning kan 
medföra i ett större samhällsperspektiv, vilket făr henne att fundera i banor hon inte har reflekterat över tidigare. Hon resonerar högt "asså man börjar redan nu och blir uppdelade på det sättet som vi är, så kommer man ju liksom senare söka sig till de människorna som man tror man har mest gemensamt med". Poneh drar analysen ett steg längre och förklarar att detta skulle kunna innebära att de i maktposition endast banar väg och anställer sina "likar". Plötsligt slår det henne och hon utbrister "wow där har vi roten till rasism". Hon rycker till och tillägger skrattade. "Nä jag skoja”. Så återfår hon allvaret i rösten och konstaterar uppgivet:

Ah, de är inte så bra! Verkligen inte bra! Men de finns inte så mycket man skulle kunna göra åt.

Maktlösheten som Poneh ger uttryck för, förekommer hos de allra flesta jag intervjuar. Nikos, vars föräldrar nyligen flyttat från Grekland för högt uppsatta jobb inom vården, talar om att han förstår sina svenska kamrater och att han antagligen hade agerat på samma sätt om han vore i deras skor. Han konstaterar att han inte vill vara här och planerar att flytta tillbaka så fort han kan. Jozef drar paralleller till ett vidare samhällsperspektiv. Samtalet engagerar honom och han växlar till arabiska, det språk som han dagligen använt fram till han flydde Syrien för ett år sedan. Han förklarar att de klasskamrater som inte vill hälsa på honom i korridoren kommer hamna:

- In the government! [växlar till arabiska] I regeringen! I riksdagen! Var som helst. Klassen är som ett litet samhälle, men de kommer att bre ut sig. Om alla skolklasser är på det viset, det är katastrof.

- Katastrof?! [arabiska]

- That's why I'm not really encouraged to stay in this country. (Jozef)

Ali är en av de drivande eleverna som ser det som sitt ansvar att få till en förändring. En dag lämnas vi ensamma i matsalen och han förklarar vikten av att kunna umgås över skilda identitetskategorier men också riskerna med att inte göra det. Likt Poneh och Jozef funderar han kring hur de sociala processerna i skolan kan relateras till en vidare samhällskontext. Han förklarar:'They are our future. They are the leaders of tomorrow. What will happen to our society if they only stick together?" Under intervjun återkommer han till ämnet och sina farhågor.

I know Hugo is aiming for politics. I know August is also aiming for politics. I know many who are aiming for politics. If these socially closed groups are the ones that are gonna someday rule the country or even run it in some way, they will maybe, I hope that's not true, make the social gap between the classes and also the people worse. (Ali) 
Att ordet rasism inte omnämns är inte konstigt. Ingen i klassen skulle beskriva sig i ordalaget och ingen skulle beskriva dem så heller. Det finns dock fog att nämna att rasistiska handlingar kan förekomma även hos uttalade antirasister (Bonilla-Silva, 2017).

\section{DISKUSSION}

Formell inkludering bidrar inte per automatik till social inkludering. Inkludering kan med andra ord inte reduceras till fysisk placering av elever under samma tak. Studiens resultat pekar mot att enbart kontakt inte räcker som grund för inkludering och vänskap (jfr Allport 1979) och vita, priviligierade elever från resursstarka hem är inte mer välvilligt inställda mot klasskamrater som inte tillhör normen (jfr Putman, 2007). På en formell nivå accepteras och uppskattas elever med utländsk bakgrund och de tillåts delta i skolans verksamhet, men stöter på mikroaggressioner $\mathrm{i}$ kontakt med dem som de kallar för svenskarna.

Mikroaggressioner är svåra att ifrågasätta, och begränsar därmed elevernas möjligheter till motstånd. Då kamraterna faktiskt svarar på tilltal, om än kort, och eftersom lärarna inte verkar se segregationen och exkluderingen som en fråga om etnicitet, blir det svårt att protestera eller påtala problem. Trots att lärarna under intervjuer säger sig ha märkt av den segregering som förekommer i klassrummet, förklarar de den i termer av olyckliga omständigheter, och agerar inte eftersom ingen öppet protesterar. Och eftersom ingen agerar eller protesterar förblir möjligheterna till förändring små. Enskilda mikroaggressioner kan ses som harmlösa, men riskerar samtidigt att bli en förutsättning för allvarlig diskriminering och rasism (Sue, 2010; jfr Allport, 1979). Dessutom upptar vetskapen om riskerna att bli utsatt för mikroaggressioner onödig tid och energi från annat viktigt såsom skolarbete och sunda vänskapsrelationer. Eleverna tvingas till ständig beredskap för avståndstaganden, avvisanden och exkluderingar och måste lära sig hantera känslor av skam, skuld, och sorg (jfr Allport, 1979).

I materialet framkommer tre strategier för att hantera mikroaggressioner och exkluderingar. En strategi är att se tillvaron som tillfällig, med planer på att en dag flytta utomlands. Problemet med denna strategi är att eleverna inte ser sin framtid i Sverige och det svenska samhället riskerar att förlora en driftig och begåvad ungdom, om flyttplanerna skulle förverkligas. Många unga människor drömmer nämligen om att flytta utomlands, men förverkligar inte planerna av olika anledningar.

En annan, återkommande strategi är att rycka på axlarna och konstatera att man inte bryr sig. Att rycka på axlarna, och intala sig själv att man inte bryr sig, är ett sätt att kontrollera det enda man kan kontrollera, sina egna reaktioner och känslor. Det handlar om att göra situationen betydelselös, i den mening att den rådande tillvaron inte har en inverkan på ens liv. 
Chanserna att förändra situationen genom protester är små och ansträngningen skulle vara alltför stor. Dessutom finns det en risk att de som påtalar problem själva blir till problemet (jfr Ahmed, 2012) genom att de ställer till det för intet ont anande och oförstående klasskamrater som utan att ha brutit mot formella regler utmålas som bad guys (jfr Bonilla-Silva, 2017). Alternativet blir att accepterna en situation man inte gillar eller att enskilda individer på egen hand söker bryta gränserna och ta tillfällen i akt när de dyker upp. Att söka bryta gränserna utgör den tredje strategin som endast en elev, Ali påtalar. Detta blir till ett projekt för den enskilde istället för ett kollektivt projekt, och skulle det lyckas förändras inte förutsättningarna för andra. Den enskilde blir bara undantagen.

Studiens resultat pekar på att daglig kontakt mellan elevgrupper inte per automatik leder till förändrade kamratrelationer och integrering, men som både Allport (1979) och Putman (2007) framhåller är förändring möjlig om auktoriteter såsom skolledning och lärare uppmärksammar och agerar mot den interna segregationen. På ett återbesök i skolan, några veckor efter avslutat fältarbete, berättar Ali att en av deras lärare nu har uppmärksammat segregationen i klassrummet och uppmanar dem att under lektioner sitta med någon de inte har pratat med under dagen. Jag erinrar mig intervjun med läraren, hur mina frågor fick honom att tänka till och hans omnämnande av strategin som ett medel att få elever att interagera. Men om detta säger jag inget till Ali, som glatt berättar att:

I actually really like the idea, because I got to talk to someone who I haven't spoken to the whole year, Patrick. I haven't spoken to him cause I thought he was such an unsocial person, because he really gives off the feeling that you can't talk to him. But he's actually a nice guy. I told some jokes and he laughed, so I think I have a chance of getting a seat with him. I'm trying my best! Ali

\section{NOTER}

${ }^{1}$ Jag använder Skolverkets (2011) definition av elever med utländsk bakgrund.

\section{REFERENSER}

Ahmed, Sara. (2010). Vithetens fenomenologi. Tidskrift för genusvetenskap, (1-2), 48-69.

Ahmed, Sara. (2012). On being included: racism and diversity in institutional life. Durham and London: Duke University Press.

Allport, Gordon W. (1979). The Nature of Prejudice. New York: Basic Books. 
Anthias, Floya. (2006). Belongings in a globalising and unequal world: rethinking translocations. I Nira Yuval-Davis, Kalpana Kannabiran och Ulrike Vieten. The Situated Politics of Belonging. London: Sage.

Azar, Michael. (2006). Den koloniala bumerangen: Frän schibbolet till körkort $i$ svenskhet. Eslöv: Symposion.

Barth, Fredrik. (1994). Introduction. I Fredrik Barth (red.) Ethnic groups and boundaries: The social organization of culture difference. Oslo: Pensumtjeneste.

Bonilla-Silva, Eduardo. (2017). Racism without racists: Color-blind racism and the persistence of racial inequality in America. Plymouth: Rowman \& Littlefield.

Braun, Virginia, \& Clarke, Victoria. (2006). Using thematic analysis in psychology. Qualitative Research in Psychology, 3(2), 77-101.

Bucholtz, Mary. (2011). White kids: Language, race and styles of youth identity. Cambridge: Cambridge University Press.

Bunar, Nihad. (2010). The geographies of education and relationships in a multicultural city enrolling in high-poverty, low-performing urban schools and choosing to stay there. Acta Sociologica, 53(2), 141-159.

Bunar, Nihad, \& Sernhede, Ove. (2013). Inledning. I Nihad Bunar \& Ove Sernhede (red.) Skolan och ojämlikhetens urbana geografi: Om skolan, staden och valfriheten. Göteborg: Daidalos.

Eriksen, Thomas Hylland. (2007). Etnicitet och nationalism. Nora: Nya Doxa.

Gaztambide-Fernandez, Rubén. (2009). The Best of the Best: Becoming Elite at an American Boarding School. Cambridge: MA: Harvard University Press.

Gruber, Sabine. (2007). Skolan gör skillnad: Etnicitet och institutionell praktik. Norrköping: Institutionen för samhälls- och välfärdsstudier, Linköpings universitet. (Diss.)

Hagström, Miriam. (2018). Raka spår, sidospår, stopp: Vägen genom gymnasieskolans språkintroduktion som ung och ny i Sverige. Linköping University Electronic Press. (Diss)

Hall, Stuart. (2000). Old and new identities, old and new ethnicities. I John Solomos $\&$ Les Back (red.) Theories of race and racism: $A$ reader. London: Routledge.

Jonsson, Rickard. (2007). Blatte betyder kompis: Om maskulinitet och språk $i$ en bögstadieskola. Stockholm: Ordfront. (Diss.)

Kallstenius, Jenny. (2010). De mångkulturella innerstadsskolorna: Om skolval, segregation och utbildningsstrategier $i$ Stockholm. Stockholm: Acta Universitatis Stockholmiensis. (Diss.)

Kuriloff, Peter. \& Reichert, Michael. (2003). Boys of Class, Boys of Color: Negotiating the Academic and Social Geography of an Elite Independent School. Journal of Social Issues, 59(4), 751-769.

Lamont, Michelle \& Molnár, Virág. (2002). The Study of Boundaries in the Social Sciences. Annual Review of Sociology, 28, 167-195. 
Langmann, Elisabeth \& Månsson, Niclas. (2016). Att vända blicken mot sig själv: En problematisering av den normkritiska pedagogiken. Pedagogisk forskning $i$ Sverige, 21(1-2), 79-100.

Lund, Stefan. (2015). School choice, Ethnic Divisions and Symbolic Boundaries. New York: Palgrave Pivot.

Marcus, George E. (1998). Ethnography through thick and thin. Princeton: Princeton University Press.

Mattsson, Katarina. (2005). Diskrimineringens andra ansikte - svenskhet och "det vita västerländska". I Masoud Kamali \& Paulina de los Reyes (red.) Bortom vi och dom: Teoretiska reflektioner om makt, integration och strukturell diskriminering: Rapport av utredning om makt, integration och strukturell diskriminering. SOU 2005:41. Stockholm: Fritzes offentliga publikationer.

Möller, Åsa. (2010). Den” goda" mångfalden. Utbildning \& demokrati. Tidskrift för didaktik och utbildningspedagogik, 19(1), 85-106.

Nilsson Folke, Jenny. (2016). 'Sitting on embers': a phenomenological exploration of the embodied experiences of inclusion of newly arrived students in Sweden. Gender and Education, 28(7), 823-838.

Olweus, Dan. (1998). Mobbning i skolan: vad vi vet och vad vi kan göra. Stockholm: Liber.

Putman, Robert D. (2007). E Pluribus Unum: Diversity and Community in the Twenty-first Century. The 2006 Johan Skytte Prize lecture. Scandinavian Political Studies, 30(2), 137-174).

Runfors, Ann. (2003). Mångfald, motsägelser och marginaliseringar: En studie av hur invandrarskap formas i skolan. Stockholm: Prisma. (Diss.)

Sernhede, Ove. (2011). School, youth culture and territorial stigmatization in Swedish metropolitan districts. Young, 19(2), 159-180.

Skolverket (2011). Skolverkets lägesbedömning 2011 Del 1 - Beskrivande data: Förskoleverksambet, skolbarnsomsorg, skola och vuxenutbildning. Barn och elever med utländsk bakgrund. Stockholm: Skolverket.

Törnqvist, Maria. (2015). Performing politics, producing privilege: Student formation at an internationally oriented Swedish upper secondary school. Centre européen de sociologie et de science politique, Working Papers.

Sue, Derald Wing. (2010). Microaggressions in everyday life: Race, gender, and sexual orientation. John Wiley \& Sons.

Wernesjö, Ulrika. (2015). Landing in a rural village: home and belonging from the perspectives of unaccompanied young refugees. Identities, 22(4), 451-467.

Wiltgren, Layal Kasselias. (2014). Stolt:: Om ungdomar, etniciteter och gemenskaper. Diss. Linköping University Electronic Press.

Wiltgren, Layal Kasselias. (2016). Etnicitet som resurs i skolan. Lund: Studentlitteratur. 
Wiltgren, Layal Kasselias. (2020). Polite exclusion: high-performing immigrant students experience of peer exclusion. Race Ethnicity and Education, 1-17. 